УДК $316.614-056.45: 305-055.25$

DOI:

Тетяна Шамсутдинова-Лебедюк, кандидат філософських наук, професор кафедри філософії Рівненського державного гуманітарного університету

Наталія Полицяк, завідувач кабінету редакційно-видавничої діяльності Рівненського обласного інституту післядипломної педагогічної освіти

\title{
СОЦІАЛІЗАЦІЯ ОБДАРОВАНИХ ДІВЧАТ ДОШКІЛЬНОГО ТА ПІДЛІТКОВОГО ВІКУ В УМОВАХ ГЕНДЕРНОЇ ДИФЕРЕНЦАЦІЇ
}

У статті проведено аналіз теоретичних праць вітчизняних та зарубіжних фахівців щчодо проблеми впливу гендерних стереотипів і диференціальної соціалізачії на обдарованих дітей, зокрема дівчат. Зауважено, що породження стереотипів досить обмежує розвиток талантів і здібностей дівчат та хлопиів, що звужує можливості у житті загалом. Здійснено актуалізацію проблем “зникаючої обдарованості" у дівчат і “подвійного ланиюга очікувань" в обдарованих дітей. На основі аналізу наукових праць окреслено вікові особливості обдарованих дівчат дошкільного та підліткового віку. Зазначається, щуо гендерна специфіка обдарованості, вираження і можливості особистості дівчат залишаються майже не вивченими. 3'ясовано, щзо стереотипізація особливо шкідлива для обдарованих дітей.

Ключові слова: обдарованість; гендерні стереотипи; диференціальна соціалізація; “зникаюча обдарованість”; “подвійний ланцюг очікувань”.

Jim. 14.

Tetyana Shamsutdynova-Lebedyuk, Ph.D.(Philosophy), Associate Professor of the Philosophy Department Rivne State University of the Humanities Nataliya Polytsyak, Head of the Editorial and Publishing Unit, Rivne Regional Institute of Postgraduate Pedagogical Education

\section{SOCIALIZATION OF GIFTED GIRLS OF PRESCHOOLAGE AND TEENAGERS IN CONDITIONS OF GENDER DIFFERENTIATION}

The article analyzes the theoretical works of domestic and foreign experts on the problem of the impact of gender stereotypes and differential socialization on gifted children, in particular, girls.

Gender stereotypes are a serious obstacle to achieving real gender equality, they lead to gender discrimination. It is noted that the generation of stereotypes severely limits the development of talents and abilities of girls and boys, which narrows the opportunities in life in general.

Such stereotyping is especially harmful for gifted children, because they mostly combine properties that are characteristic of both their own sex and the opposite.

It is gender stereotypes that emerge on the basis of gender roles and act as norms for women and men are models for gender-role socialization and consolidate existing gender differences and become an obstacle to change in the field of gender relations. In view of this, a strategy aimed at socially constructing gender differences differential socialization - is a key factor in promoting gender inequality.

The problems of "disappearing giftedness" in girls and the "double chain of expectations" in gifted children, which connects both boys and girls, have been actualized. The boy is taught to succeed, and the girl is taught to demonstrate that she does not achieve anything and will never achieve. According to some educators, a loser boy and a lucky girl risk the same thing: they will never be elected by the opposite sex.

The article also notes that the gender specifics of giftedness, expression and personal capabilities of girls remain almost unexplored.

Therefore, these problems necessitate further in-depth study of the impact of gender stereotypes on the talents of girls, because the purpose of education in a humanistic society is to help effectively realize human potential. There is no need to make women more like men; it is necessary to help both girls and boys to become competent and productive adults who enjoy family and work.

Keywords: giftedness; gender stereotypes; differential socialization; "disappearing giftedness"; "double chain of expectations".

П остановка проблеми. Сучасне суспільство сьогодні зазнає глобальних змін, що охопили всі сфери життєдіяльності людини. 3 моменту народження дитина занурена в інформаційно насичене середовище, що породжує нові труднощі. I це не дивина, адже останні десятиліття характеризуються прискореним темпом розвитку комп'ютерних технологій, що визначають, зокрема, і розвиток дитини. Тому нині акцентується увага на 


\section{СОЦІАЛІЗАЦІЯ ОБДАРОВАНИХ ДІВЧАТ ДОШКІЛЬНОГО ТА ПІЛЛТКОВОГО ВІКУ В УМОВАХГЕНДЕРНӦ̈ ДИФЕРЕНЦІАЦЇ̈}

особливостях розвитку та умовах формування особистості обдарованих дітей. Хоча у зарубіжній i вітчизняній психології та педагогіці i нагромаджено безліч досліджень щодо обдарованості, проте вивчення гендерних відмінностей та їх впливу на багатогранність особистості розглядалося недостатньо широко. Залишається ще низка складних питань, які вимагають змістовних обгрунтувань. Крім того, своєчасною психолого-педагогічною проблемою, що потребує розв'язання, вбачається вивчення гендерних особливостей обдарованих дітей, а саме дівчат.

Аналіз останніх досліджень і публікацій. Феномен обдарованості є найбільш досліджуваним щодо питання природи, сутності, структури, типів, видів і методів діагностики. Такі психологи, як Л. Виготський, Д. Ельконін та ін. відзначають, що рушійними силами розвитку та становлення особистості $\epsilon$ спілкування і діяльність. Дослідження Ю. Бабаєвої, Н. Лейтеса, Л. Токарєвої, Л. Туріщевої, О. Щебланової присвячені розгляду основних труднощів у навчанні та вихованні обдарованих дітей у навчальних закладах освіти.

На жаль, гендерна специфіка обдарованості дітей, iї прояви та розвиток практично не вивчені. Хоча ще Л. Виготський зазначав, що особливості вікової динаміки пов'язані з розгалуженням трьох ліній розвитку: загальноорганічного, соціального й статевого (гендерного). Гендерні особливості прояву здібностей розглядалися у дослідженнях Д. Кімури, Л. Попової, Н. Орєшкіної, Б. Хасана та ін.

Водночас вплив гендеру на розвиток обдарованості в дівчат дошкільного та підліткового віку на прояви і потенціал їхньої особистості залишається майже не вивченим.

Метою статті $\epsilon$ розкриття значущості проблеми “зникаючої обдарованості” та недостатня увага до вивчення специфіки гендерної соціалізації обдарованих дівчат у вітчизняній науці, що створюють як зовнішні, так і внутрішні бар'єри реалізації обдарованості.

Виклад основного матеріалу. Структурні нерівності та постійні гендерні стереотипи, що впливають на жінок та чоловіків, дівчат та хлопців, усе ще існують у системі освіти й догляду за дітьми.

Гендерні стереотипи - це упереджені соціальні та культурні шаблони чи ідеї, згідно з якими чоловіків та жінок наділяють такими характеристиками й функціями, що визначені й обмежені їхньою статтю. Гендерні стереотипи серйозна перешкода для досягнення реальної гендерної рівності, вони призводять до дискримінації за ознакою статі. Формування таких стереотипів може обмежити розвиток природних талантів і здібностей дівчат та хлопців, жінок та чоловіків, їхні наукові та професійні вподобання й досвід, а також можливості у житті загалом [14].

Гендерні стереотипи є результатом і причиною глибоко вкорінених ставлень, цінностей, норм і упереджень.

Складним моментом у вивченні гендерних особливостей є також роль культури. Навіть коли ми можемо спостерігати відмінності в структурі мозку, вони можуть бути результатом виховання, а не природи.

Мозок є надзвичайно пластичним, тобто він формується під впливом досвіду та тренування. I, як помітила британська дослідниця Джина Ріппон, дівчата і хлопці від самого народження можуть мати дуже різний досвід, оскільки суспільство непомітно заохочує їх до певної поведінки [13].

Порушена проблема гендеру незаперечна, особливо це стосується геніальності й обдарованості жінок та дівчат. Адже впродовж століть вважалося, що геніальність - прерогатива чоловіків. Так, А. Шопенгауер стверджував, що сенс існування жінок - у дітонародженні, а для цього геніальних здібностей не потрібно. Геній проявляється переважно у чоловіках і якщо буває притаманний жінкам, то виявляється в них значно меншою мірою. “Жінки можуть володіти значним талантом, але ніколи не бувають геніальними, тому що вони завжди суб' єктивні...” [4; 1].

Легко помітити явну невідповідність між шкільними успіхами дівчат і їх досягненнями у зрілому віці.Ця невідповідність була названа С. Олшен “зникаючою обдарованістю”, ㄲï неможливо пояснити тільки біологічними причинами (наприклад, розходженнями у будові мозку або наявністю різних гормонів). Адже народжується однакова кількість обдарованих дівчат і хлопців, але 3 віком обдарованість дівчат поступово перетворюється на міф або у виняток із правила [9]. Тому, як зазначала Маргарет Мід, американський етнограф та антрополог, “вирішення завтрашніх дорослих проблем залежить у значній мірі від того, як наші діти ростуть сьогодні".

Дані свідчать, що принаймні половину всіх обдарованих дітей, виявлених у початковій школі, становлять дівчата. До моменту переходу в старші класи їх виявляється менше однієї четвертої. У “дорослому” світі жінка-керівник, лідер в освіті чи промисловості, науці чи політиці - відносно рідкісне явище [3].

Нейробіолог Дж. Ріппон стверджує, що вже у 


\section{СОЦІАЛІЗАЦІЯ ОБДАРОВАНИХ ДІВЧАТ ДОШКІЛЬНОГО ТА ПІЛЛТКОВОГО ВІКУ В УМОВАХГЕНДЕРНОЇ ДИФЕРЕНЦАЦІї}

два роки діти дуже чутливі до типової поведінки певної статі. Спостерігаючи за ними, бачимо як вони грають ролі, що личать їм за гендерною ознакою. Дивно, як рано виявляються у дитячих іграх статеві стереотипи поведінки. Безсумнівно, такі стереотипи розвиваються - можливо, і неусвідомлено - у сім'ї. Деякі педагоги сприймають і навіть розвивають ці стереотипи. Вчителі часто говорять, що батьки бувають незадоволені, коли педагог намагається зламати стереотипізацію за ознакою статі, відповідно до якої хлопці повинні грати в кубики і машинки, рухатися під звуки маршів, натомість дівчатам варто няньчити ляльок, займатися прибиранням, танцювати під “прозору”, легку музику.

Згідно з Дж. Ріппон, діти - “крихітні соціальні губки, які поглинають соціальну інформацію”, i переймаючи ту чи іншу форму поведінки, поступово перепрограмують нейронні мережі свого мозку [13].

Подібна стереотипізація особливо шкідлива для обдарованих дітей, тому що вони здебільшого поєднують у собі властивості, характерні як для їх власної статі, так і для протилежної. Однак схоже синтезування ніколи не віталося суспільством. Традиційне визначення “чоловічого” характеру включає такі якості, як незалежність, наполегливість, дух суперництва, схильність до роздумів, прагнення новизни, емоційна стриманість і самоствердження. Аналогічне визначення “жіночого” базується на чутливості у міжособистісному спілкуванні, залежності, пасивності, відсутності наполегливості, намаганні уникнути суперництва, відданості, емоційності, інтуїції, вразливості та дбайливості.

Маргарет Мід ще у 1949 р. писала про так званий “подвійний ланцюг очікувань”, що зв’язує і хлопців, і дівчат. Хлопця навчають досягати успіху, а дівчину - демонструвати, що вона нічого не домагається і ніколи не досягне. На ії думку, хлопець-невдаха і удачлива дівчина ризикують одним і тим самим: вони ніколи не будуть обрані представником протилежної статі.

"У багатьох суспільствах хлопців виховували на основі дуже простого прийому, просто навчаючи їх не бути жінками”, - висловлювалася Маргарет Мід [8].

Практика виховання та очікування різняться ще до народження дитини, про що свідчить і різна реакція на плач немовлят - до дівчат підходять швидше, заспокоюють їх частіше. Пізніше на прогулянках матері тримають їх ближче до себе. Таким чином, дівчатам почасти несвідомо навіюють буквально 3 пелюшок, що вони залежать від інших, що вони самі не можуть впоратися із ситуацією. Однак добре відомо, що активність, самостійність, впевненість у собі необхідні для розвитку високого рівня інтелекту [7]

Iз народження дівчат навчають бути пасивними, слухняними, проявляти турботу про інших. Очікують, що вони віддадуть перевагу спокійним іграм і заняттям, що не будуть схильні брати участь у ризикованих справах.

Дослідження гендерних відмінностей обдарованих дітей дошкільного віку, як і розгортання ознак обдарованості в цей віковий період, $є$ недостатньо опрацьованими питаннями. Томузвертаємося допрацьВ.Дружиніната Дж. Фрімена, в яких автори наголошують на необхідності прослідкувати гендерні особливості обдарованих дітей, починаючи 3 дошкільного віку. На їхню думку, в зв'язку з тим, що частота прояву обдарованості в дошкільників різної статі неоднакова, саме гендерні відмінності можуть стати особливо значущими в оцінці та розвитку здібностей дітей цієї вікової групи [12].

Певний дискримінаційний вплив на дівчину може мати навіть дитячий одяг. Якщо батьки, скажімо, збираються йти в гості чи на прогулянку, то доньку часто намагаються прикрасити - тут і спідничка 3 мереживом, і модне взуття, i вигадлива зачіска 3 пишними бантами... Однак такий стиль суттєво обмежує можливості дитини, вона не може почуватися вільно, бігати й торкатися “брудних речей”, , адже їі наставляють бути чистенькою, не м’яти сукню. Дівчина не має можливості вгамувати власну допитливість, бо радше заклопотана тим, як зберегти своє вбрання у первинному вигляді. Так формується стереотип про жінку як більш пасивну та одержиму власною зовнішністю істоту [2].

Дошкільний період дитинства - це той час, у процесі якого дорослі повинні зрозуміти дитину і допомогти їй розкрити ті унікальні можливості, які дані для неї своєю статтю.

Саме гендерні стереотипи, котрі виникають на основі гендерних ролей та виступають як норми для жінок і чоловіків, є моделями для гендернорольової соціалізації, закріплюють наявні гендерні розбіжності та стають завадою до змін у сфері гендерних відносин. Зважаючи на це, стратегія, що спрямована на соціальне конструювання відмінностей між статями, - диференціальна соціалізація - $є$ ключовим фактором у сприянні гендерній нерівності. Важливим інструментом диференціальної соціалізації $є$ іграшки, тобто точні копії предметів, що існують у реальному світі. Вони не просто оточують і розважають дітей, а розвивають певні компетентності, дають можливість “приміряти” дорослі ролі. 


\section{СОЦІАЛІЗАЦІЯ ОБДАРОВАНИХ ДІВЧАТ ДОШКІЛЬНОГО ТА ПІДЛТТКОВОГО ВІКУ В УМОВАХ ГЕНДЕРНОЇ ДИФЕРЕНЦАЦІЇ}

За даними американських дослідників, дитяча кімната хлопця ширше розкриває навколишній світ - у ній машинки, дидактичні ігри, конструктори, спортивний інвентар, тварини, військові іграшки. У дитячій кімнаті трирічних хлопців у середньому в три рази більше іграшок, ніж у їх ровесниць. Багато категорій іграшок зовсім не представлені у дитячих кімнатах дівчат.

У спогадах про дитинство обдарованих дівчатпідлітків містяться численні згадки про те, що їм давали ті іграшки, які батьки вважали підходящими для них, а не ті, яким вони самі надавали перевагу.

Водночас зауважимо, що близькість до батька, ідентифікація з ним дає змогу дівчинці дошкільного віку набути незалежність, активність - необхідні якості для реалізації себе у житті, та зробити іiі більш логічною, менш чутливою, що означає більш успішною у розумовій діяльності, а не у художній творчості. Протожіночність утруднить для багатьох дівчат-дошкільнят набуття якостей, необхідних для реалізації себе у геніальній художній творчості. Для того, щоб обдарована дівчина зберегла потенціал у творчості, їй необхідно ідентифікуватися із обома батьками [11].

Меншовартість “жіночого” у суспільстві утруднює розвиток позитивної Я-концепції дівчини дошкільного віку. Приналежність до соціальної групи, що володіє меншими можливостями та владою, породжує проблеми зі становленням жіночої ідентифікації, особливо якщо дівчинка володіє високими соціальними здібностями, у тому числі і лідерськими $[7 ; 6]$.

Дівчат менше націлюють на високі досягнення, вони отримують менш розгорнуту оцінку своїх дій, ніж хлопчики. Їх характеризують як менш розвинутих (винахідливих, допитливих), але більш довірливих, поступливих. Прояв незалежності у судженнях, оригінальність мислення в обдарованих дівчат іноді викликає негативну реакцію педагогів. Таке ставлення породжує у них емоційні проблеми. Вони маскують свою обдарованість, щоб бути прийнятими суспільством. Тому в міру їх дорослішання i проявляється феномен “зникаючої обдарованості” дівчат, який розглядає психолог Л. Попова. На основі конкретних соціологічних досліджень та наукових узагальнень, вона робить висновок про те, що орієнтованість дівчат у процесі соціалізації на обслуговування сім'ї певною мірою визначає їх майбутній занижений соціальний статус. На соціологічному матеріалі автор переконливо демонструє, що “конструювання гендерних компонент особистості проходить протягом усього дошкільного віку” [11].
Подібну тенденцію окреслила і дослідниця Н. Конопльова: суспільство, орієнтоване на жорсткі уявлення про те, що є “чоловіче" та “жіноче”, нерідко відкидає та пригнічує обдарованість саме через “порушення правил поведінки, приписаних біологічній статі людини, в означеному випадку - дитині” [5].

Дівчат готують до репродуктивного життя, “хорошої” поведінки, пригнічення власної ініціативи (конформності). У школі цей процес також триває - численні закордонні дослідження показали, що шкільні вчителі в класі приділяють більше уваги хлопцям. Учителі передовсім відповідають на їхні запитання, а однокласниць до питань не заохочують. Ідеться про те, що дівчинка повинна знати, а не досліджувати i сумніватися в істинності чи повноті знання. Крім того, що вчителі частіше відгукуються на різні види активності хлопців, вони також дають якісно інший зворотний зв'язок хлопцям і дівчатам. Будьяка відповідь дівчини приймається (з тією чи іншою оцінкою), але від хлопців вимагають більшого, наполягають на пошуку правильного чи більш раціонального рішення. Їхнім відповідям також дається більш розгорнута характеристика, на основі якої можна робити подальший аналіз.

Варто зауважити, що вчителі по-різному пояснюють і погані досягнення учнів різної статі: неуспіх дівчат - відсутністю здібностей, хлопців - недоліком працьовитості, зусиль. Ця відмінність має велике значення, оскільки за відсутності здібностей працьовитість, додаткові зусилля не розв'яжуть проблему. Отже, дівчат менше налаштовують на роботу, їх заохочують прийняти те, що є, як належне. I навпаки - хлопців стимулюють працювати більше, щоб домогтися успіху.

У школі вчителі продовжують зусилля сім'ї 3 формування різного типу поведінки у дівчат і хлопців. Помічено, що вигуки $з$ місця, дрібні порушення дисципліни, допущені дівчатами, викликають обурення вчителів, тоді як хлопцям ті ж дії залишалися безкарними. 3 боку вчителів і батьків на дівчат здійснюється сильний тиск для того, щоб змусити їх беззаперечно підкорятися всіляким нормам, правилам і традиціям.

Неоднаковим $є$ також ставлення вчителів до обдарованих учнів різних статей. Так, учителі вважають, що обдаровані хлопці перевершують обдарованих однокласниць в галузі критичного та логічного мислення, у творчому розв'язання завдань. Також педагоги ставлять найнижчі оцінки тим ученицям, які виявляють здібності до аналітичного мислення, до висунення власних оригінальних ідей, чинять опір традиційним 


\section{СОЦІАЛІЗАЦІЯ ОБДАРОВАНИХ ДІВЧАТ ДОШКІЛЬНОГО ТА ПІЛЛТКОВОГО ВІКУ В УМОВАХГЕНДЕРНОЇ ДИФЕРЕНЦАЦІї}

умовностям. Хлопціз подібними характеристиками мають серед учителів високий рейтинг. Упереджене ставлення до обдарованих учениць особливо небезпечне, оскільки дівчата більш сприйнятливі до реакції вчителів.

У результаті всіх цих, на перший погляд, малозначимих відмінностей обдаровані дівчата йдуть у дорослий світ з деякими досить поширеними рисами. По-перше, багато хто з них заперечує свою обдарованість та неабиякі здібності, пояснюючи успіхи зовнішніми умовами. По-друге, у них формується виняткова здатність до соціальної адаптації, добре маскується обдарованість, що забезпечує прийняття їх найближчим оточенням. По-трете, вони змінюють свої первинні професійні орієнтації, часто зі зниженням соціального статусу професії. I замість того, щоб радіти своїй багатогранності та повноті життя, обдарованим дівчатам доводиться постійно боротися проти стереотипів суспільного сприйняття.

Отже, у боротьбі проти тиску соціальних стереотипів батьківська підтримка важлива для обдарованих дітей обох статей, але особливо для дівчат. Тому батькам важливо не бути конформістами, адже саме вони повинні розвивати в дітях сильний характер та мотивацію з метою вільного розвитку як хлопців, так і дівчат.

Висновки та перспективи подальших досліджень. Означені у статті проблеми зумовлюють потребу поглибленого дослідження впливу гендерних стереотипів на обдарованість дівчат, адже мета освіти у гуманістичному суспільстві - допомогти ефективно реалізувати людські можливості, допомогти і дівчатам, і хлопцям стати компетентними та продуктивними дорослими, які отримують задоволення від сім'ї та роботи.

\section{ЛІТЕРАТУРА}

1. Вейнингер О. Пол и характер. Москва, 2004. 494 c.

2. Дружинин В.Н.Психология общих способностей. Санкт-Петербург : Питер, 2006. 249 с.

3. Clark B. Growing up gifted. Columbus, $\mathrm{OH}$ : Merrill Publishing, 2013.

4. Ковалевский П.И. Психиатрические эскизы из истории. Москва, 1995. Т.1. 544 с.

5. Кузнєц Д. В. Вплив гендерного чинника на розвиток обдарованості дітей. Наукові записки Малої академії наук Украӥни. 2016. Вип. № 8. C. 160 .

6. Лейтес Н. С. Психология одаренности детей и подростков / под ред. Н. С. Лейтеса. Москва : Издательский дом “Академия”, 1996. 416 с.
7. Марущенко О., Плахотнік О. Гендерні шкільні історії. Харків : Монограф, 2012. 88 с.

8. Мид М. Мужское и женское. Исследование полового вопроса в меняющемся мире. Москва : РОССПЭН, 2004. 412 c.

9. Olshen S. R. The disappearance of giftedness in girls : An intervention strategy. Roeper Rev. № 9. 1987. P. 251-254.

10. Полицяк Н. І. Вплив гендерних стереотипів на соціалізацію обдарованих дівчаток. Обдаровані діти - скарб нації: матеріали II Міжнародної науково-практичної онлайнконференції (18-22 серпня 2021 року). Київ, 2021.

11. Попова Л. В. Гендерная социализация в детстве. Гендерныц подход в дошкольной педагогике: теория и практика: монографія: в 2-х ч. Мурманск, 2001. Ч.1. С. 231.

12. Попова Л. В. Проблема самореализации одаренных женщин. Вопросы психологии. № 2. 1996. С. 31-42.

13. Риппон Дж. Гендерный мозг. Издательство “Форс", 2019. 400 с.

14. Стратегія гендерної рівності ради Свропи на 2018-2023 роки.

URL : https://rm.coe.int/prems-041318-gbrgender-equality-strategy-2023-ukr-new2/ 16808b35a4 (дата звернення: 16.07.2021).

\section{REFERENCES}

1. Veyninger, O. (2004). Pol i kharakter [Gender and character]. Moscov, 494 p. [in Russian].

2. Druzhinin, V. N. (2006). Psikhologiya obshchikh sposobnostey [Psychology of general abilities]. Sankt-Peterburg, 249 p. [in Russian].

3. Clark, B. (2013). Growing up gifted. Columbus, $\mathrm{OH}$ : Merrill Publishing. [in English].

4. Kovalevskiy, P.I. (1995). Psikhiatricheskie eskizy iz istorii [Psychiatric sketches from history]. Moscov. Vol.1.544 p.[in Russian].

5. Kuzniets, D. V. (2016). Vplyv hendernoho chynnyka na rozvytok obdarovanosti ditei [The influence of gender on the development of children's talents]. Scientific notes of the Small Academy of Sciences of Ukraine.Vol. 8. p. 160. [in Ukrainian].

6. Leytes, N. S. (1996). Psikhologiya odarennosti detey i podrostkov [Psychology of giftedness of children and adolescents]. (Ed.).N. S. Leytesa. Moscov, 416 p. [in Russian].

7. Marushchenko, O. \& Plakhotnik, O. (2012). Henderni shkilni istorii [Gender school stories]. Kharkiv, 88 p. [in Ukrainian].

8. Mid, M. (2004). Muzhskoe i zhenskoe. Issledovanie polovogo voprosa $\mathrm{v}$ menyayushchemsya mire [Male and female. Sexual research in a changing world]. Moscov, 412 p. [in Russian]. 
9. Olshen, S. R. (1987). The disappearance of giftedness in girls : An intervention strategy. Roeper Rev. No.9. pp. 251-254. [in English].

10. Polytsiak, N. I. (2021). Vplyv hendernykh stereotypiv na sotsializatsiiu obdarovanykh divchatok [The influence of gender stereotypes on the socialization of gifted girls]. Obdarovani dity - skarb natsii: materialy II Mizhnarodnoi naukovopraktychnoi onlain-konferentsii (18-22 serpnia 2021 roku) - Gifted children - the treasure of the nation: materials of the II International scientificpractical online conference (August 18-22, 2021). Kyiv. [in Ukrainian].

11. Popova, L. V. (2001). Gendernaya sotsializatsiya $\mathrm{v}$ detstve [Gender socialization in childhood]. Gender approach in preschool pedagogy: theory and practice: monograph: in 2 hours.Murmansk. Part.1.p. 231. [in Russian].

12. Popova, L. V. (1996). Problema samorealizatsii odarennykh zhenshchin [The problem of selfrealization of gifted women]. Psychology issues.No.2. pp. 31-42. [in Russian].

13. Rippon, Dzh. (2019).Gendernyy mozg [Gender brain]. Izdatelstvo "Fors". 400 p.[in Russian].

14. Stratehiia hendernoi rivnosti rady Yevropy na 2018-2023 roky [Council of Europe Gender Equality Strategy for 2018-2023]. Available at: https:// rm.coe.int/prems-041318-gbr-gender-equalitystrategy-2023-ukr-new2/16808b35a4 (accessed 16 July.2021). [in Ukrainian].

Стаття надійшла до редакції 03.09.2021

УДК 378:004.9

DOI:

Тетяна Мастеркова, викладач кафедри суспільно-гуманітарних дисчиплін Комунального закладу “Житомирський ОІППО” Житомирської обласної ради

\section{ПРОФЕСІЙНІ СПІЛЬНОТИ ЯК ЧИННИК РОЗВИТКУ ФАХОВОЇ КОМПЕТЕНТНОСТІ ПЕДАГОГА}

У статті охарактеризовано діяльність педагогічних професійних спільнот як чинник основи професійноособистісного становлення і розвитку педагога. Особливість діяльності професійних спільнот в умовах онлайнспілкування передбачає вдосконалення рівня цифрової компетентності учасників для організацї̈ родуктивного користування віртуальним простором спільноти. Стаття містить визначення професійних спільнот, розроблені основні критерії изиррових навичок для вимірювання рівня цииррової компетентності освітянина.

Ключові слова: професійні спільноти; професійна компетентність; професіоналізм; самопрезентація; саморозвиток; траєкторія професійного розвитку педагогічних працівників.

Табл. 1. Літ. 6.

Tatyana Masterkova, Lecturer of the Social and Humanitarian Branch of Science Department, Communal Educational Institution “Zhytomyr Regional In-Service Teachers' Training Institute”, Zhytomyr Regional Council

\section{TRADE UNIONS AS A FACTOR OF PROFESSIONAL DEVELOPMENT OF TEACHER COMPETENCES}

The article outlines the main activities of pedagogical professional communities to provide methodological support for the professional development of teachers in the period of online communication. Professional selfdetermination and self-realization of a teacher, along with professional orientation and socialization, act as constituent elements of the structure of his professional and personal formation and development.

Features of the creation and existence of professional communities of teachers in the online space involves improving the level of digital competence of participants to organize the productive use of virtual community space. Unlike traditional professional communities, which can exist without active voluntary communication, in online communities communication is a necessary prerequisite for stable support for the association of colleagues.

In the course of group activity of the community the self-organization of pedagogical workers on the principles of individual usefulness and satisfaction of inquiries of separate participants is provided. The intrinsic motivation of participants' communication needs and the development of approaches to assessing the teacher's professional growth explain the existence of an online community that brings people together in the long run.

In the course of the research the bases for long-term stable existence of modern online communities are studied, the organizational structure of the community is revealed, the typology of its members is carried out, an interaction, the results of community activity and their social effects are analyzed.

The article formulates the definition of professional communities, offers the main criteria for assessing digital skills to measure the level of digital competence of the educator. 